University of New Hampshire

University of New Hampshire Scholars' Repository

Law Faculty Scholarship

University of New Hampshire - Franklin Pierce

School of Law

$1-1-2014$

\title{
Noel Canning and Remedial Obligation Under the Constitution
}

John M. Greabe

University of New Hampshire School of Law

Follow this and additional works at: https://scholars.unh.edu/law_facpub

Part of the Constitutional Law Commons

Comments

Copyright is owned by the Virginia Law Review Association and the article is used by permission of the Virginia Law

Review Association. Abstract available at http://ssrn.com/abstract=2480651

\section{Recommended Citation}

John M. Greabe, "Noel Canning and Remedial Obligation Under the Constitution," 100 VA L. REV. ONLINE 47 (2014).

This Article is brought to you for free and open access by the University of New Hampshire - Franklin Pierce School of Law at University of New Hampshire Scholars' Repository. It has been accepted for inclusion in Law Faculty Scholarship by an authorized administrator of University of New Hampshire Scholars' Repository. For more information, please contact sue.zago@law.unh.edu. 


\title{
VIRGINIA LAW REVIEW ONLINE
}

\section{ESSAY}

\section{NOEL CANNING AND REMEDIAL OBLIGATION UNDER THE CONSTITUTION}

\author{
John M. Greabe
}

\section{INTRODUCTION}

FTER the Supreme Court issued its decision in National Labor Re-
lations Board v. Noel Canning, ${ }^{1}$ many observers expressed relief that the ruling's disruptive effect was likely to be relatively contained. ${ }^{2}$ True, the Court unanimously concluded that President Obama violated the Constitution's Recess Appointments Clause when, in 2012, he appointed three commissioners to the National Labor Relations Board ("NLRB") during a very brief, "intra-session" Senate recess. ${ }^{3}$ But a majority of the Justices explicitly rejected Noel Canning's broader claims, accepted below by the U.S. Court of Appeals for the D.C. Circuit, that

\footnotetext{
${ }^{*}$ Professor of Law and Faculty Chair, Warren B. Rudman Center for Justice, Leadership \& Public Policy at the University of New Hampshire School of Law. I am grateful to Professor Toby Heytens, who, in reviewing an earlier article of mine, posed the question that this essay addresses. I also thank my UNH Law colleague Professor Leah Plunkett for extremely helpful comments and suggestions on an earlier draft. Finally, I thank the editors of the Virginia Law Review Online - in particular, Derrick Aud and Sean Park - for deciding to publish my essay and for their excellent editorial assistance.

${ }^{1} 134$ S. Ct. 2550 (2014).

${ }^{2}$ I say "likely" because the Noel Canning Court did not discuss how its decision should be operationalized.

${ }^{3}$ An "intra-session" Senate recess occurs within one of the two one-year Senate sessions that are held between each congressional election. By contrast, an "inter-session" Senate recess occurs between the two sessions. See Noel Canning, 134 S. Ct. at 2560-61.
} 
the Constitution bars the President from making any recess appointments during intra-session Senate recesses, and from using the recess appointments power to fill any vacancies extant prior to the recess in which the appointment is made. Amy Howe, writing for SCOTUSblog, explained why the nation had dodged a bullet with this comparatively modest decision:

So what exactly does all of this mean, going forward? First and foremost, it means that the three recess appointments directly involved in this case - to the NLRB - are invalid. That in turn means that any decisions in which those three NLRB commissioners participated while they were recess appointees are invalid. But nothing in the Court's ruling suggests that it would invalidate other, earlier recess appointments. To the contrary, the Court made clear that, over two centuries, presidents had made only a very small handful of recess appointments during recesses that were [too brief to allow for a recess appointment]. And later on, it contrasted its approach with that of Justice Scalia whose approach, it contended, "would render illegitimate thousands of recess appointments reaching all the way back to the founding era."4

As the quoted passage shows, conclusions such as "invalid" tend to flow naturally from the premise "unconstitutional," especially where, as in Noel Canning, the unconstitutional act in question implicates a government agent's power to act. But to assume that the decisions of the improperly appointed NLRB commissioners are void as a constitutional matter-the clear implication of the descriptor "invalid"-is to default to ontological characterization, rather than to analyze the question of what to do about the decisions in the procedural contexts in which it will arise, as legal realism teaches. Such an assumption thus prevents us from asking the right questions about remedial obligation under the Constitution in the wake of Noel Canning.

In fact, when we situate the question within a broader and more contextually appropriate analysis of when courts regard remedies for constitutional violations to be constitutionally compelled, we see that there is little reason to assume that the decisions of these commissioners are ipso

\footnotetext{
${ }^{4}$ Amy Howe, Court Strikes Down Recess Appointments: In Plain English, SCOTUSblog (June 26, 2014, 3:13 PM), http://www.scotusblog.com/2014/06/court-strikes-down-recessappointments-in-plain-english/.
} 
facto without legal effect. In future cases, courts asked to provide remedies for the constitutional wrong identified in Noel Canning may well decide to invalidate Board decisions in which the improperly appointed commissioners participated. ${ }^{5}$ But that would be a question of remedial lawmaking as a matter of constitutional common law. The Constitution would not require them to do so.

This Essay explains why in three parts. Part I summarizes the facts and procedural history of the Noel Canning decision. Part II elaborates on why we should not assess the question of remedial obligation under the Constitution after Noel Canning "in the air" ${ }^{\text {" }}$ and outside of the procedural contexts in which it will arise (if it does in fact arise ${ }^{7}$ ) in future court cases. Part III argues that, when we situate the question of remedy for the constitutional wrong identified in Noel Canning within a broader look at when courts regard remedies for constitutional violations to be constitutionally compelled, we see that invalidation of the appointees' decisions is not required by the Constitution. This Essay concludes with some preliminary thoughts about how, with the question of constitutional necessity put to the side, courts and other entities responsible for implementing remedies might develop doctrines appropriate for use in circumstances such as those presented after Noel Canning and, more generally, after a government official who has purported to act under color of law is found to have been improperly empowered by an appointing authority.

\footnotetext{
${ }^{5}$ This assumes, of course, that the NLRB will not concede decisional invalidity or otherwise take actions that will keep the issue from arising in future litigation. Compare, e.g., the NLRB's response to New Process Steel, L.P. v. NLRB, 560 U.S. 674 (2010). New Process Steel held that the NLRB lacks authority to make decisions or take actions without a lawfully appointed quorum - that is, three out of its five Board members under 29 U.S.C. § 153(b) (2012). From January 2008 until March 2010, the NLRB operated with three of its five seats vacant. During that time, the two Board members issued about 550 decisions. Following the Supreme Court's ruling, the NLRB took measures to obviate additional court challenges to these 550 decisions. The NLRB issued a statement summarizing these measures. See Press Release, National Labor Relations Board, Background Materials on Two-Member Board (on file with author).

${ }^{6}$ Cf. Palsgraf v. Long Island R. Co., 162 N.E. 99, 99 (N.Y. 1928) (observing that legal concepts such as negligence must be given content relationally and contextually, and that "[p]roof of negligence in the air, so to speak, will not do") (citation and internal quotation marks omitted).

${ }^{7}$ See supra note 5 and accompanying text.
} 


\section{NOEL CANNING: ESSENTIAL BACKGROUND ${ }^{8}$}

The Constitution provides two ways in which the President may appoint federal officers. The principal method is charted in the Appointments Clause, Article II, Section 2, Clause 2, which states that the President

shall nominate, and by and with the Advice and Consent of the Senate, shall appoint Ambassadors, other public Ministers and Consuls, Judges of the supreme Court, and all other Officers of the United States, whose Appointments are not herein otherwise provided for, and which shall be established by Law: but the Congress may by Law vest the Appointment of such inferior Officers, as they think proper, in the President alone, in the Courts of Law, or in the Heads of Departments. ${ }^{9}$

The Appointments Clause thus requires Senate confirmation of "principal" (that is, non-"inferior") "Officers," and also has been read to require Senate confirmation of those "inferior Officers" that Congress by statute makes subject to presidential appointment with the advice and consent of the Senate. ${ }^{10}$

The Constitution also makes provision for presidential appointments when the Senate is in recess. This second method is described in the Recess Appointments Clause, Article II, Section 2, Clause 3, which states: "The President shall have Power to fill up all Vacancies that may happen during the Recess of the Senate, by granting Commissions which shall expire at the End of their next Session." 11

The NLRB, a federal agency empowered to investigate and adjudicate unfair labor practices, is comprised of up to five "Officers" appointed by

\footnotetext{
${ }^{8}$ A recent Congressional Research Service Report provides a more detailed recitation of the background to the Noel Canning decision. See David H. Carpenter and Todd Garvey, Cong. Research Serv., R43032, Practical Implications of Noel Canning on the NLRB and CFPB 2-5 (2013), available at http://www.cfpbmonitor.com/files/2013/04/Practical-Implications.pdf.

${ }^{9}$ U.S. Const. art. $2, \S 2$, cl. 2.

${ }^{10}$ Officers of the United States, whether principal or inferior, are persons who exercise significant authority pursuant to the laws of the United States. See, e.g., Buckley v. Valeo, 424 U.S. 1, 126 (1976). They must be appointed in accordance with the Appointments Clause or Recess Appointments Clause. Id. Officers subject to appointment may be contrasted with federal employees, who are lesser functionaries subordinate to United States officers. Id. at 126, n.162.

${ }^{11}$ U.S. Const. art. 2, $\S 2$, cl. 3.
} 
the President with the advice and consent of the Senate. ${ }^{12}$ On January 4, 2012, President Obama invoked the Recess Appointments Clause to appoint Terrence F. Flynn, Sharon Block, and Richard F. Griffin, Jr., as three of these officers. ${ }^{13}$ The Senate was then in a three-day, intrasession Senate recess because, on December 17, 2011, it had by unanimous consent adopted a resolution to take a series of brief recesses beginning the next day, December 18, 2011, and concluding on January 23, 2012, when it planned to return for ordinary business. ${ }^{14}$ Pursuant to that resolution, the Senate would hold pro forma sessions (at which no Senate business would be conducted) every Tuesday and Friday until the January 23, 2012 return for ordinary business. ${ }^{15}$ January 4, 2012 fell on a Wednesday, between the pro forma sessions held on Tuesday, January 3, 2012, and Friday, January 6, 2012. ${ }^{16}$ As of that date, Flynn's nomination had been pending in the Senate for approximately a year, while the nominations of Block and Griffin had been pending for several weeks. ${ }^{17}$

Following these appointments, on February 8, 2012, the NLRB (a majority of which was then comprised of President Obama's three January 4,2012 , recess appointees) issued an administrative decision concluding that Noel Canning, a bottler and distributor of Pepsi products, had unlawfully failed to reduce to writing and execute a collective bargaining agreement with a labor union. ${ }^{18}$ Noel Canning challenged the lawfulness of this determination before the D.C. Circuit Court of Appeals, arguing that the three commissioners who joined the Board pursuant to President Obama's January 4, 2012, recess appointments had been invalidly appointed, and that the Board therefore lacked the quorum necessary for it to proceed. ${ }^{19}$ The D.C. Circuit agreed and issued a broad decision hold-

\footnotetext{
${ }^{12}$ See 29 U.S.C. $\$ 153($ a) (2012).

13 Noel Canning, 134 S. Ct. at 2557.

${ }^{14} \mathrm{Id}$.; see also id. at 2573-76 (accepting that the Senate was actually in session on those days that served to subdivide the period from December 17, 2011, to January 23, 2012, into a series of short, intra-session recesses).

${ }^{15} \mathrm{Id}$. at 2557.

${ }^{16} \mathrm{Id}$.

${ }^{17} \mathrm{Id}$.

${ }^{18}$ Noel Canning, 358 N.L.R.B. No. 4 (2012); see also Noel Canning, 134 S. Ct. at 2557.

${ }^{19}$ Noel Canning, 134 S. Ct. at 2557; see also 29 U.S.C. $\$ 160(f)$ (2012) (providing for judicial review before the D.C. Circuit); id. $\$ 153$ (b) (providing for a three-member quorum); New Process Steel, L.P. v. NLRB, 560 U.S. 674, 687-88 (2010) (holding that the Board cannot exercise its statutory powers in the absence of a lawfully appointed quorum).
} 
ing that the appointments were unlawful because the President cannot invoke the Recess Appointments Clause to make appointments either during intra-session Senate recesses or to fill vacancies that pre-date the recess in which they are made. ${ }^{20}$

The Supreme Court unanimously affirmed the D.C. Circuit's judgment that the appointments in question were not lawfully made under the Recess Appointments Clause. ${ }^{21}$ But a majority of the Justices explicitly rejected the D.C. Circuit's conclusion that the Clause neither authorizes appointments during intra-session recesses nor permits appointments to fill vacancies that were extant prior to the recess in which they are made. ${ }^{22}$ Instead, the majority narrowly ruled that the three-day, intrasession recess during which the challenged appointments were made was simply too brief a recess to trigger the President's power under the Clause. ${ }^{23}$ Henceforth, a Senate recess "of more than 3 days but less than 10 days [will be] presumptively too short to fall within the [Recess Appointments] Clause." 24

\section{NOEL CANNING AND REMEDIAL Obligation UNDER THE}

CONSTITUTION: THE NECESSITY OF CONTEXTUALIZING THE INQUIRY

As noted above, it seems natural to view the question of remedial obligation under the Constitution after Noel Canning as simple and straightforward in view of the Court's holding that NLRB Commissioners Flynn, Block, and Griffin were unconstitutionally appointed to their offices. The logic of such an argument would run as follows: All decisions handed down by the NLRB through these commissioners were made without a quorum; therefore, all decisions handed down by the NLRB through these commissioners were made without the constitu-

\footnotetext{
${ }^{20}$ Noel Canning, 134 S. Ct. at 2557-58 (summarizing the D.C. Circuit's holdings, which are set forth in an opinion published at 705 F.3d 490 (D.C. Cir. 2013)).

${ }^{21}$ Id. at 2578; see also id. at 2592 (Scalia, J., concurring, joined by Chief Justice Roberts, Justice Thomas, and Justice Alito).

${ }^{22}$ See id. at 2561.

${ }^{23}$ Id. at 2566.

${ }^{24}$ Id. at 2567. The majority explained why it hedged a bit in its holding: "We add the word 'presumptively' to leave open the possibility that some very unusual circumstance-a national catastrophe, for instance, that renders the Senate unavailable but calls for an urgent response - could demand the exercise of the recess-appointment power during a shorter break." Id. '
} 
tionally requisite government power; as a result, all decisions handed down by the NLRB through these commissioners are null and void as a constitutional matter.

By one account, acceptance of such a line of analysis would result in the nullification of some 700 reported and unreported decisions issued by the NLRB from January 4, 2012, until the end of July $2013,{ }^{25}$ when the impasse over President Obama's NLRB nominees was finally resolved by Senate confirmation of five new appointees. ${ }^{26}$ It also might be thought to call into question the legality of enforcement actions brought by ten regional directors of the NLRB who were approved by the tainted Board, and prior delegations of authority from the tainted Board to its Acting General Counsel. ${ }^{27}$ But happily-at least for those who do not welcome the introduction of chaos into government functioning-this binary, legitimate/illegitimate take on the issue is rooted in a formalistic and anachronistic approach to legal analysis that skirts the question future courts may well have to decide: Is a party aggrieved by a decision of what proved to be an improperly constituted NLRB entitled to the remedy of judicial vacatur as a matter of constitutional right?

One of the most valuable lessons of legal realism is that we tend to take wrong turns when we reify transcontextual legal concepts such as "government power" and assume that they contain ontological characteristics that are ascertainable outside of the various procedural contexts in which our legal system gives them definition. As Judge Posner colorful-

\footnotetext{
${ }^{25}$ See G. Roger King \& Bryan J. Leitch, The Impact of the Supreme Court's Noel Canning Decision-Years of Litigation Challenges on the Horizon for the NLRB, 60 Construction Lab. Rep. (BNA) No. 2973, at 521 (July 10, 2014), available at http://www.bna.com/impactsupreme-courts-n17179891624/.

${ }^{26}$ The Senate confirmed five appointees to the NLRB on July 30, 2013. See Ramsey Cox, Senate confirms all five NLRB members, The Hill (July 30, 2013, 10:15 PM), http://thehill.com/ blogs/floor-action/senate/314503-senate-votes-to-confirm-all-five-nlrb-members.

${ }^{27}$ King \& Leitch, supra note 25, at 521-22. Note, however, that "[o]n July 18, 2014, the National Labor Relations Board unanimously ratified all administrative, personnel, and procurement matters taken by the Board from January 4, 2012 to August 5, 2013." Press Release, National Labor Relations Board, NLRB Officials Ratify Agency Actions Taken During Period When Supreme Court Held Board Members Were Not Validly Appointed (Aug. 4, 2014), available at https://www.nlrb.gov/news-outreach/news-story/nlrb-officials-ratifyagency-actions-taken-during-period-when-supreme-court. Then, on July 30, 2014, regional directors appointed by the Board during that time period ratified all actions they took, or that were taken on their behalf, during that same time period. See id.
} 
ly put it in a discussion of "domicile" which, like the concept of government power, arises in a number of different legal domains:

Unfortunately, in this age of second homes and speedy transportation, picking out a single state to be an individual's domicile can be a difficult, even a rather arbitrary, undertaking. Domicile is not a thing, like a rabbit or a carrot, but a legal conclusion, though treated as a factual determination for purposes of demarcating the scope of appellate review. And in drawing legal conclusions it is always helpful to have in mind the purpose for which the conclusion is being drawn. The purpose here is to determine whether a suit can be maintained under the diversity jurisdiction, a jurisdiction whose main contemporary rationale is to protect nonresidents from the possible prejudice that they might encounter in local courts. ${ }^{28}$

One need not concede the accuracy of Judge Posner's description of diversity jurisdiction's main contemporary rationale, or approve of the manner in which he conducts his purposive analysis, to appreciate the incisiveness of the point that legal concepts must be given content in a contextually sensitive manner.

The same point may be made with respect to the concept of government power-even government power that derives entirely from the Constitution - through principles familiar to every first-year law student. A court may have the constitutional power to adjudicate a claim against a foreign defendant, but simultaneously lack the constitutional power to adjudicate a different claim over which it has subject matter jurisdiction against the same foreign defendant. ${ }^{29}$ Government power with respect to that defendant is not an on/off switch. Indeed, even within the context of subject matter jurisdiction-the strictest and least forgiving of government-power concepts - matters are not binary. It may well be that subject matter jurisdiction either exists or does not exist with respect to one party's claim against another party. But that does not mean that a final judgment issued by a court later shown to lack subject matter jurisdiction over the claim is a legal nullity as a matter of constitutional law. In fact, courts typically will not set aside final judgments as to which appellate rights have expired on a mere showing that the adjudicating court

\footnotetext{
${ }^{28}$ Galva Foundry Co. v. Heiden, 924 F.2d 729, 730 (7th Cir. 1991).

${ }^{29}$ See, e.g., Int'l Shoe Co. v. Washington, 326 U.S. 310, 318 (1945).
} 
lacked subject matter jurisdiction over the claim at the time of adjudication. ${ }^{30}$ Rather, courts asked to vacate judgments on this ground look to a separate body of law - the law of remedies - in determining what they should do.

This last point is telling for purposes of analyzing how to evaluate remedial obligation under the Constitution after Noel Canning. As with the concepts of personal and subject matter jurisdiction, to say that the NLRB acted without constitutional authority during the period when three of its commissioners were improperly appointed is not necessarily to say that all actions taken by the Board during the period in question must be treated as legal nullities under the Constitution. A subset of the law of remedies - that governing a court's discretion to fashion or withhold remedies for wholly concluded constitutional violations, depending on what the public interest requires-should guide the analysis. Under that body of law, Noel Canning should not be seen to render automatically void, as a matter of constitutional law, all decisions of the improperly appointed commissioners.

\section{NOEL CANNING AND REMEDIAL OBLIGATION UNDER THE CONSTITUTION: LESSONS FROM THE LAW OF CONSTITUTIONAL REMEDIES}

The Noel Canning decision is not, of course, the first time that the Supreme Court has held that a government agent purporting to act under color of law did not lawfully hold the power it had been exercising. For example, in Nguyen v. United States, the Court vacated judgments affirming criminal convictions entered by a Ninth Circuit panel that unlawfully included an Article IV territorial court judge. ${ }^{31}$ Similarly, in Ryder v. United States, the Court vacated a Court of Military Appeals decision upholding a conviction affirmed by a panel of the Coast Guard Military Review despite the fact that the panel included two judges who were unconstitutionally appointed under the Appointments Clause. ${ }^{32}$

On the civil side, in Northern Pipeline Construction Co. v. Marathon Pipe Line Co., the Court upheld a judgment dismissing an adversary

\footnotetext{
${ }^{30}$ See Durfee v. Duke, 375 U.S. 106, 111-12 (1963); Chicot Cnty. Drainage Dist. v. Baxter State Bank, 308 U.S. 371, 376 (1940); Stoll v. Gottlieb, 305 U.S. 165, 176-77 (1938).

${ }^{31} 539$ U.S. 69, 71-73 (2003).

${ }^{32} 515$ U.S. 177,179 (1995).
} 
proceeding brought by a party in bankruptcy against a third party on the ground that the federal statute purporting to allow the bankruptcy judge to adjudicate the proceeding constituted an unconstitutional grant of Article III adjudicatory jurisdiction to an Article I court. ${ }^{33}$ And, in Buckley v. Valeo, the Court invalidated as unconstitutional under the Appointments Clause the appointments of four members of the Federal Election Commission. ${ }^{34}$

It is interesting to compare and contrast how the Court treated the question of remedy - an issue that, again, the Noel Canning Court did not address-in these four cases. In Buckley, even though the Court invalidated the Commissioners' appointments, it also held: "[T]he Commission's inability to exercise certain powers because of the method by which its members have been selected should not affect the validity of the Commission's administrative actions and determinations to this date .... The past acts of the Commission are therefore accorded de facto validity ...." Similarly, in Northern Pipeline, the Court held that its judgment should only apply prospectively, and the Court stayed the entry of judgment for a period of time so that Congress could, in the inter$\mathrm{im}$, restructure the bankruptcy courts in a constitutional manner. ${ }^{36}$ But in the more recent Ryder and Nguyen decisions, the Court took a more formalistic approach.

In Ryder, the Court rebuffed the government's entreaty to follow Buckley's remedial holding, which the government had characterized in its briefing as an application of the "de facto officer doctrine." The de facto officer doctrine is an old rule that "confers validity upon acts performed by a person acting under the color of title even though it is later discovered that the legality of that person's appointment or election to office is deficient." ${ }^{37}$ The Ryder Court noted that Buckley had not explicitly relied on the de facto officer doctrine and that, even if its remedial

\footnotetext{
${ }^{33} 458$ U.S. 50, 87-88 (1982).

${ }^{34} 424$ U.S. 1, 143 (1976) (per curiam).

${ }^{35}$ Id. at 142 . The Court also issued a temporary stay to provide "Congress an opportunity to reconstitute the Commission ...., allowing the present Commission in the interim to function de facto in accordance with the substantive provisions of the [Federal Election Campaign] Act." Id. at 143.

${ }^{36}$ See Northern Pipeline, 458 U.S. at 88.

${ }^{37}$ Ryder, 515 U.S. at 180 (citing Norton v. Shelby County, 118 U.S. 425, 440 (1886)).
} 
holding might be regarded as a species of that doctrine, it should not be extended beyond its facts. ${ }^{38}$ The Ryder Court also distinguished three prior criminal cases in which the de facto officer doctrine was applied because Ryder had raised a timely objection to the judges' appointments before the panel that included those judges, and Ryder's complaint was rooted in the Appointments Clause and not the mere "misapplication of a statute." 39 And the Court brusquely dismissed the government's request that it apply its holding only prospectively. ${ }^{40}$

In Nguyen, the majority brushed aside the fact that Nguyen had first raised his challenge before the Supreme Court, and it differentiated between the "merely technical" statutory defects in earlier cases where the de facto officer doctrine was applied and the one before it, which the Court described as involving "a strong policy concerning the proper administration of judicial business." ${ }^{41}$ Indeed, in vacating Nguyen's conviction, the majority quoted a line from a nineteenth century case that comes very close to expressing the binary, ontological view of government power that this Essay seeks to refute: "If the statute made [the judge] incompetent to sit at the hearing, the decree in which he took part was unlawful, and perhaps absolutely void, and should certainly be set aside or quashed by any court having authority to review it by appeal, error or certiorari." ${ }^{42}$

So do these cases teach anything that is useful? At best, they demonstrate that courts need a rationalized set of remedial doctrines to apply following a holding that an agent of government-corporate or humanpurporting to act under color of law lacked the constitutional authority to wield the adjudicatory power that it had been exercising. But that is about all that can be said on their behalf. So the question therefore becomes, how should courts rule when faced with a request to vacate the decisions of a government agent subsequently found to have been improperly appointed?

\footnotetext{
${ }^{38}$ See id. at $183-84$.

${ }^{39}$ Id. at 182 .

${ }^{40}$ See id. at $184-85 \&$ n. 3 .

${ }^{41}$ Nguyen, 539 U.S. at 77-78 (citation and internal quotation marks omitted).

${ }^{42}$ Id. at 78 (quoting American Constr. Co. v. Jacksonville, T. \& K. W. R. Co., 148 U.S. 372,387 (1893)).
} 
As should by now be clear, I do not favor the formalistic answer that all decisions of such an agent are automatically null and void. Consider the disruptive effect on government operations such a rule would engender and the distortive, law-freezing pressures it would bring to bear on judges reluctant to unleash chaos through an exercise of judicial review. ${ }^{43}$ But more can be said against such a rule than that it is unattractive from a practical perspective. As sketched above in Part II, and explained in greater detail below, it also would be entirely at odds with the modern Court's approach to remedies for constitutional violations in cases, such as Noel Canning, Nguyen, Ryder, and Buckley, where the constitutional violation in question was wholly concluded at the time the Court addressed its merits. ${ }^{44}$

Nor do I favor the resuscitation of selectively prospective judicial rulings through non-retroactivity doctrines, as some thoughtful commentators have advocated in support of broader arguments that courts must develop new ways to manage the costs of constitutional innovation. ${ }^{45}$ The Supreme Court appropriately removed from the judicial toolbox selectively prospective rulings ${ }^{46}$ and, more generally, all forms of nonretroactive judicial rulings in Griffith $v$. Kentucky ${ }^{47}$ and Harper v. Va. Dep't of Taxation. ${ }^{48}$ As I argue in a forthcoming article, ${ }^{49}$ selectively prospective judicial rulings materially differ from other, legitimate doc-

\footnotetext{
${ }^{43}$ See, e.g., John C. Jeffries, Jr., Disaggregating Constitutional Torts, 110 Yale L.J. 259, 271-75 (2000) (explaining that there would be far less constitutional innovation by courts without remedy-limiting doctrines that reduce the costs of such innovation).

${ }^{44}$ Northern Pipeline differs from these other cases in that the party with standing to press the constitutional claim before the Supreme Court had never suffered a constitutional violation because the lower courts had not unconstitutionally forced it to litigate before an Article I court. See 458 U.S. at $56-57$.

${ }^{45}$ See Toby J. Heytens, The Framework(s) of Legal Change, 97 Cornell L. Rev. 595, 599600 (2012); Toby J. Heytens, Managing Transitional Moments in Criminal Cases, 115 Yale L.J. 922, 927 (2006); Richard H. Fallon, Jr. \& Daniel J. Meltzer, New Law, NonRetroactivity, and Constitutional Remedies, 104 Harv. L. Rev. 1731, 1735-36 (1991).

${ }^{46}$ Selectively prospective rulings benefit only the litigant in the case announcing the ruling and any party affected by future conduct of the sort being held unlawful. In Stovall v. Denno, 388 U.S. 293, 301 (1967), the Court held that Article III requires that rulings announcing new rights benefit the parties in the cases in which they are announced.

${ }^{47} 479$ U.S. $314,316,328$ (1987) (holding that courts may not issue non-retroactive rulings on direct review of criminal convictions).

${ }^{48} 509$ U.S. 86, 90 (1993) (extending Griffith to the civil context).

${ }^{49}$ See John M. Greabe, Remedial Discretion in Constitutional Adjudication, 62 Buff. L. Rev. 881 (forthcoming 2014), available at http://ssrn.com/abstract=2305629.
} 
trines that withhold remedies for wholly concluded constitutional violations - for example, the qualified-immunity rule ${ }^{50}$ exceptions to the exclusionary rule, ${ }^{51}$ harmless-error rules,${ }^{52}$ and the remedy-limiting rule of Teague v. Lane applicable on collateral review. ${ }^{53}$ Unlike these other doctrines, selectively prospective judicial rulings violate the norms of Article III by treating similarly situated litigants differently and permitting courts to issue purely advisory opinions that function as prospective legislation. ${ }^{54}$

Moreover, selectively prospective rulings are unnecessary for managing the costs of constitutional change. Although it has not adequately explained itself, the modern Court has charted a constitutionally appropriate course in developing and applying doctrines that act to withhold remedies for constitutional violations in those cases-but only in those cases-where withholding a remedy for such a violation is constitutionally permissible and otherwise in the public interest. Buried within the Court's unrationalized yet largely principled pattern of behavior, we find the answer to the question whether the Constitution places courts under an unyielding obligation to vacate the decisions of unconstitutionally appointed government officials when parties with standing ask them to do so. The answer to that question is no.

The key lies in appreciating the different ways the Court has handled ongoing and wholly concluded constitutional violations from a remedial perspective. While the Court has properly regarded the judiciary as under an obligation to halt ongoing constitutional violations rooted in government custom or policy (at least so long as the issue is raised by means of a justiciable claim in a proper forum), it also has appropriately regarded the subconstitutional, substitutionary remedies sought when the wrong in question is wholly concluded at the time of adjudication as

\footnotetext{
${ }^{50}$ See, e.g., Harlow v. Fitzgerald, 457 U.S. 800, 813, 819 (1982).

${ }^{51}$ See, e.g., United States v. Leon, 468 U.S. 897, 926 (1984).

${ }^{52}$ See, e.g., Chapman v. California, 386 U.S. 18, $22-24$ (1967).

${ }^{53}$ See 489 U.S. $288,300-10$ (1989). This remedy-limiting doctrine is, unfortunately, still unhelpfully characterized as a species of non-retroactivity doctrine on occasion. See Chaidez v. United States, 133 S. Ct. 1103,1105 (2013). For more on why this is a mischaracterization, see Greabe, supra note 49 , at 5 n. 9 .

${ }^{54}$ See Greabe, supra note 49 , at $37-41$.
} 
contingent and subject to being withheld when the public interest so requires. Both of these points are further discussed in recent work. ${ }^{55}$

For present purposes, it suffices to observe that the post-hoc judicial vacatur of a decision rendered by an unconstitutionally appointed government agent is much like an award of damages to the victim of a constitutional tort; or the exclusion of evidence at the trial of a victim of a Fourth, Fifth, or Sixth Amendment violation; or the vacatur on appeal of a judicial judgment infected by constitutional trial error. Like these other subconstitutional forms of remedy, ${ }^{56}$ such a vacatur cannot halt or undo the constitutional wrong. Rather, it serves only to provide a party with substitutionary relief for the constitutional harm suffered. ${ }^{57}$ And as with these other forms of remedy, it can have significant, negative consequences for innocent third parties ${ }^{58}$ who may have planned their affairs in reliance on the validity of the decision or act that is being challenged. Thus, as with these other forms of substitutionary remedy, the decision whether to issue such a vacatur is properly balanced against the public interest.

To be sure, substitutionary remedies for constitutional violations are vital to the proper functioning of our constitutional system. Indeed, the Supreme Court has gone too far in restricting their availability in a number of contexts. ${ }^{59}$ But they inherently differ from specific remedies di-

${ }^{55}$ See id.; see also John M. Greabe, Constitutional Remedies and Public Interest Balancing, $21 \mathrm{Wm}$. \& Mary Bill Rts. J. 857, 859-60 (2013).

${ }^{56}$ Because the Supreme Court has repeatedly observed that the federal Constitution provides no right to an appeal, see, e.g., M.L.B. v. S.L.C., 519 U.S. 102, 110 (1996), and because the Constitution certainly does not guarantee other procedural mechanisms by which one can seek to reopen or attack a final judgment, decision, or act by a government agent, there certainly can be no freestanding constitutional right to a remedy whose delivery mechanism is a matter of legislative grace.

${ }^{57}$ Note that the adverse effect of the unconstitutionally appointed official's decision or act may well be ongoing from the perspective of the victim. But this adverse effect is not the constitutional violation. The violation, rather, is that an entity exercised government power on the claimant when it should not have held that power in the first instance. This subtle point is perhaps best illustrated by noting, for example, that the constitutional claimant in Noel Canning might well have been found to have engaged in a violation of federal labor law by a properly constituted NLRB.

${ }^{58}$ Cf. People v. Defore, 150 N.E. 585, 587 (N.Y. 1926) (Cardozo, J.) ("The criminal is to go free because the constable has blundered.").

${ }^{59}$ See John M. Greabe, A Better Path for Constitutional Tort Law, 25 Const. Comment. 189, 192-93 (2009) (similar); John M. Greabe, Iqbal, al-Kidd and Pleading Past Qualified Immunity: What the Cases Mean and How They Demonstrate a Need to Eliminate the Im- 
rected at ongoing constitutional violations rooted in custom or policy, whose constitutional necessity is strongly implied by the existence of a judiciary entrusted with judicial review to help maintain the separation of powers, our federalist structure, and individual rights. I have already mentioned their tendency to impose costs on innocent third parties, and their inability to halt or undo the wrong at which they are directed. They also tend in the main to be responsive not to unconstitutional custom or policy - that is, unconstitutionality at the law-making level-but rather, to the wholly concluded discretionary decisions and acts of those many individuals in whom we necessarily entrust government power at the federal, state, and local levels. They are important, and they usually should be available. But they are not, and should not be, automatically available as a matter of constitutional right for every wholly concluded constitutional wrong.

\section{CONCLUSION}

If one accepts that vacatur of the decisions and acts of unconstitutionally appointed government agents is not constitutionally compelled, we must begin fashioning remedial doctrines appropriate for contextual application. My preliminary view is that we would simplify things enormously if we did away with exotica such as the de facto officer doctrine, accepted the demise of non-retroactivity doctrines, and viewed the issue through much the same lens as the harmless-error and plain-error doctrines that courts apply in deciding whether to vacate judicial judgments infected by constitutional errors committed by judges and prosecutors in

munity Doctrines from Constitutional Tort Law, 20 Wm. \& Mary Bill Rts. J. 1, 2 (2011) (arguing that the Supreme Court should reform the qualified-immunity doctrine in a number of respects); John M. Greabe, Mirabile Dictum!: The Case for "Unnecessary" Constitutional Rulings in Civil Rights Damages Actions, 74 Notre Dame L. Rev. 403, 408 (1999); John M. Greabe, Objecting at the Altar: Why the Herring Good Faith Principle and the Harlow Qualified Immunity Doctrine Should Not Be Married, 112 Colum. L. Rev. Sidebar 1, 3 (2012) (arguing for a narrower concept of "good faith" in formulating exceptions to the exclusionary rule); John M.M. Greabe, Spelling Guilt Out of a Record? Harmless-Error Review of Conclusive Mandatory Presumptions and Elemental Misdescriptions, 74 B.U. L. Rev. 819 , 820-21 (1994) (arguing for a narrower concept of harmless error with respect to instructional errors that interfere with the jury's fact-finding function). 
connection with criminal trials. ${ }^{60}$ Errors of the sort committed by the President in Noel Canning are certainly "structural," and they certainly are of constitutional dimension. When challenged in a timely way at any point in a direct review process, they certainly should yield a remedy. ${ }^{61}$ But like other structural errors, they should be subject to forfeiture rules if they have not been timely raised,$^{62}$ and they should not automatically yield relief when challenged post-hoc through collateral attack mechanisms. ${ }^{63}$ Most importantly, their availability to individual litigants should always be balanced against the public interest and, in particular, the chaos and costs that they are likely to engender.

\footnotetext{
${ }^{60}$ See Chapman v. California, 386 U.S. 18, 21-22 (1967) (detailing how constitutional errors should be reviewed for harmlessness); United States v. Olano, 507 U.S. 725, 731-32, 736 (1997) (detailing how claims of error that have been forfeited should be reviewed for plain error under Fed. R. Civ. P. 52(b)).

${ }^{61}$ Cf. Neder v. United States, 527 U.S. 1, 7 (1999) (acknowledging that structural errors as to which appellate rights have been preserved should automatically yield a remedy).

${ }^{62}$ Cf. Johnson v. United States, 520 U.S. 461, 466 (1997) (stating that structural errors are not subject to automatic reversal but rather should be reviewed for plain error under Fed. R. Civ. P. 52(b) and Olano).

${ }^{63}$ Cf. Coleman v. Thompson, 501 U.S. 722,750 (1991) (stating that all procedurally defaulted federal claims cannot be pressed on collateral review unless there are both cause for the default and prejudice resulting therefrom).
} 